\title{
India-Brazil-South Africa (IBSA) - a new geography of trade and technology cooperation?
}

\begin{abstract}
The India-Brazil-South Africa (IBSA) Dialogue Forum, was established in 2003, as a political alliance of three likeminded, democratic, developing countries in order to counterbalance the traditional North-South power asymmetry. The vision of the political leaders, however, goes beyond a lose political union, and aspires South-South cooperation in trade, science and technology. The paper explores what the available evidence suggests regarding the possible depth and outreach of the project.
\end{abstract}

\section{The creation of and rationale behind IBSA}

The Declaration of Brasilia, signed in June 2003 by the foreign ministers of India, Brazil and South Africa, established the IBSA Dialogue Forum - a geopolitical arrangement between three rather like-minded democracies of the South (Interrnet: http://www.ibsa-trilateral.org/brasil_declaration.htm, 3.1.2008). The IBSA initiative has been coined by some authors as the G3, a possible counterweight to the G7 or G8, alliances of the most influential industrialized countries. IBSA was initially launched with a keen political focus and a strong emphasis on multilateral coalition building. Although this political element remains a central pillar of the initiative, the alliance has quickly moved beyond this, to focus more broadly on other concrete linkages, such as promoting trade relations, security, and cooperation in science and technology. DRAPER/ MiLLs/White (2004) argue, that this dynamic was faster than what the three IBSA leaders had initially anticipated, particularly considering that IBSA was launched by a meeting of foreign ministers and not by the heads of states.

The IBSA cooperation is evolving against the background of similar levels of poverty, unemployment, and difficulties with social inclusion afflicting the three countries involved. But it is also evolving against the background of political and economic changes in the post cold war international system that resulted in the emergence of new patterns of cooperation among countries of the developing world, crossing regional boundaries (HURREL 2006). Increasing trade and investment flows among developing economies reflect this trend. As an alternative to the traditional patterns of North-South trade, consisting primarily of commodity exports in exchange for imports of manufactured goods from developed countries, South-South trade and investment co-operation has become an increasingly important economic alternative for those developing countries. As a result, core Southern states began forging closer strategic and institutional alliances in order to enhance their growth and development (see UNCTAD 2005; KEET 2006).

It is within this context that India, Brazil and South Africa, all three politically and economically influential states in a changing global context, found the unique opportunity to move countries of the South to the centre of the new and emerging global order. Having acknowledged their middle power capabilities and interests, these anchor countries have united to strengthen their bargaining power and achieve common gains in multilateral forums. (see FLEMES 2007; TAYLOR 2005) However, given the uneven distribution of trade and develop- 
ment among developing countries, it is also imperative that these anchor countries use their weight to act as the "locomotives of the South", to ensure that developing countries concerns remain high on the global agenda (see White 2004, 2006; AldEN/VIEIRA 2005).

An example of this, and possibly IBSA's first tangible success, was over the pharmaceutical patents dispute for anti-retroviral HIV medication, in response to the US. IBSA has subsequently initiated trilateral cooperation to bolster research and development of infectious and traditionally neglected diseases such as HIV/AIDS, malaria and tuberculosis. The three anchor countries pledged to increase investments in vaccine research and development, and have also pledged to improve access to new preventative medical technologies through mechanisms such as the agreement on Trade Related Aspects of Intellectual Property Rights (TRIPS) (FLEMES 2007, 13). IBSA members were also opposed to the proposed European Union Registration, Evaluation and Authorisation of Chemicals (REACH) legislation. In March 2006, at the meeting of foreign ministers in Rio de Janeiro, IBSA countries showed opposition to REACH legislation which they believed would have detrimental impacts for their export of chemical, metal and mineral products to the European Union (Internet: http://www.dfa.gov.za/docs/2006/ibsa 0331.htm, 3.1.2008).

Since its inception in Brasilia 2003, IBSA has held four annual ministerial meetings and two summit meetings (one in September 2006 in Brazil and the other in October 2007 in South Africa). From the outset, a broad agenda for cooperation was established and synthesised into the ambitious New Delhi Plan of Action (Internet: http://www.dfa.gov.za/docs/2004/ibsa0305a.htm, 3.1.2008. Five Memoranda of Understanding have been signed on agriculture and allied fields, bio-fuels, merchant shipping and other maritime transport, trade facilitation and a framework for cooperation on information society. There are currently fourteen sectoral working groups operating within the forum, ranging from climate change, human settlement development, to health and corruption. In the following the available information on the trends in trade among the three IBSA countries and the prospects for increased science and technology cooperation among them will be analyzed. These two fields may be con- sidered key in strengthening the tripartite alliance. Following this analysis, there will be a provisional outlook drawn on the future perspectives of IBSA, highlighting promising developments to date as well as potential barriers to further cooperation.

\section{Boosting development through trade - a motivation for South-South cooperation - the heart of IBSA?}

The idea that developing countries should attempt to stimulate their development through South-South trade cooperation is nothing new (see Singer/Hatti/TANDON 1988; South Centre 1996). It has been part of the activities of the Non-Aligned Movement and Group of 77 (G77). There are two major objectives for developing countries to promote intra-south trade alliances (see e.g. AVRAMOvic 1988; LANGHAMMER 1988):

- Exports are to be diversified successfully to become less dependent on the revenues from a limited range of exports to the markets of the industrialised countries. Non-diversified export economies - especially if exports are concentrated in raw materials or agricultural products - are vulnerable to volatile prices of world markets thus significantly limiting the chances of the economies to cope with external shocks even in times when the domestic economy shows a good performance.

- Industrial development and technological upgrading are to be stimulated through the transfer of technology. Due to the similar level of technological development, the stimulated competition is not likely to result in an immediate collapse of local industries - as opposed to cases were a quick market liberalisation would lead to crowding out by products and companies from industrialised countries due to the technological development asymmetries. In contrast, a stimulation of a rather healthy competition in manufactured products, that are in the beginning not high end standard or rather specialised to the needs of people in developing countries, are expected to be a key opportunity for a mutual gradual upgrading of production technology.

But in most cases these hoped for developments did not take place on a sufficient level to 
reduce either the dependence on exporting raw materials to the industrialised countries nor did a diversification of exports to developing countries take place on a large scale. Reasons for this are manifold. Examples include:

- The trade routes which have existed since colonial times were and still are in many cases much better developed and frequented than other South-South routes, thus making it easier and more profitable to scale up trade on existing routes instead of developing new ones.

- Developing new trade patterns is associated with high search costs. In many cases this led to a lack of willingness or financial resources of the public and the private sector to continuously promote and deepen new trade connections.

- Insufficient transport infrastructure (crossborder highways, ports, airports) and a lack of planning and financial capacity to develop it among developing countries, made SouthSouth trade unprofitable in many cases.

- Despite positive rhetoric about South-South solidarity, continued high levels of market protection by developing countries for products from other developing countries prohibited access to new markets.

However, since the late 1980s official statistics show a steady increase in South-South trade that accelerated especially in recent years. According to Kumar/Agarwala 2006) SouthSouth trade was growing at $10 \%$ during the period 1990-2001, twice as fast as global trade. In between 2000-2003 these growth rates were further increasing to $14.2 \%$ compared to 5.2 $\%$ for global trade. South-South trade nowadays accounts for nearly $43 \%$ of total trade of developing countries and $11 \%$ of world trade. The title of UNCTAD's 2005 Trade and Development Report "New features of global interdependence" (UNCTAD 2005) hints at this global economic shift: The astonishing development of Asian economies (e.g. Malaysia, South Korea, Taiwan, Thailand and more recently also Vietnam and Cambodia), plus the rise of China and India, have led to an immense increase in intra regional trade in Asia due to specialization and production sharing.

In addition to that, rapidly growing anchor countries like Brazil and South Africa over- came their regional isolation due to the political changes that occurred in the mid 1980s in Brazil and respectively in the early 1990s in South Africa. Subsequently both anchor countries were able to increase exports to existing markets of the developed countries, and moreover, considerably increase their trade exchange with other anchor countries and their regional neighbours. The establishment of the Mercado Común del Sur (Mercosur) in 1991 was a major step for Brazil's political and economic reintegration into South America. Regarding South Africa, the Southern African Development Co-ordination Conference (SADCC), an organisation of the former African anti-apartheid frontline states, was reformed to the Southern African Development Community (SADC) in 1992; South Africa joined the SADC in 1994.

A third factor given by UNCTAD (2005) that deserves attention is the by now large size of rapidly growing economies in developing regions (especially the aforementioned Brazil, China, India and South Africa). These anchor countries are in some sectors nowadays even on a comparable technological level regarding products and the production process to developed countries and they are technically advanced compared to many countries in their respective regions. These southern economic powerhouses source raw materials or semi-processed goods from developing countries for value adding and subsequent export to the North. On the other hand their advanced production technology in proximity of markets of less developed countries creates new possibilities to sell manufactures. These regional economic asymmetries which are stimulating intra regional economic linkages lead us to the image of "economic locomotives" for the anchor countries. This observation might also offer an explanation for the rather limited success of earlier South-South trade initiatives. The often similar level of technological development and production resulted in non-existing complementarities and constituted rather limited market opportunities for expanding trade among developing countries. Therefore the increasing difference in economic size, technological development and sectoral specialisation in developing regions can be seen as a trigger for increasing intra and inter regional South-South trade. This development is also reflected in an increase of South-South foreign direct investment (FDI). AYKUT/RATHA (2003) 
estimate that South-South FDI has risen from $5 \%$ of all FDI flows to the South in 1994 to $30 \%$ in 2000. With regard to this South-South FDI, UNCTAD (2006) argues that with its distinctive characteristics this FDI may be closer to those of enterprises in the host developing countries thus providing increased opportunities for host countries to benefit from inward FDI.

Summing up these developments KUMAR/ Agarwala $(2006,1)$ conclude: "the South is no longer one 'backward' group. Different countries and even sub-regions within the countries are at vastly different 'stages of development'. Thus the complementarities within the group have increased tremendously. The South working as a bloc can help each other in the vital areas such as trade, finance, investment, energy, environment, labour mobility, technology, designing of development strategy, and correcting global imbalances in an orderly fashion."

And just recently this has also been emphasised in the report of the Secretary-General of UNCTAD to UNCTAD XII (UNCTAD 2007, $4,25)$ : “A 'second generation' of globalization is thus emerging. A distinctive characteristic of this phase of globalization is economic multipolarity, in which the South plays a significant role. (...) The new economic weight of some developing countries creates significant opportunities for the rest of the developing world.(...) The promotion of South-South trade remains a desirable objective because of the market and investment opportunities that it offers to low-income developing countries." Given this background and the recent revival of South-South trade initiatives (see ANTKIEWICZ/WHALLEY 2006), IBSA provides an interesting new concrete project at the beginning of the $21^{\text {st }}$ century. It is therefore important to provide a closer look at IBSA's early stages of development and track them to date.

\section{New geography of trade? IBSA economies and their current trade relations}

"It is essential to carry on building a new world economic and commercial geography which, while maintaining the vital ties to developed countries, allows for the establishment of solid bridges among the countries of the South, which have remained isolated from one another for too long. (Braziliạn president, Luiz Inácio Lula da Silva 2004) ${ }^{1}$. From this statement, it is evident that Brazil's president sees the dawning of a "new world economic and commercial geography" and UNCTAD's director of the Division on International Trade in Goods, Services and Commodities, Lakshmi Puri, recently referred to IBSA as "an emerging trinity in the new geography of international trade" (PURI 2007). Two main questions arise regarding the trade component of the $I B$ SA Dialogue Forum: a) Does the political rhetoric of South-South solidarity around IBSA result in increasing trade among the three anchor countries? b) What is known about the potential for increasing trade among IBSA countries that would justify the high hopes expressed in recurring joint statements?

India, Brazil and South Africa - three anchor countries on the move

Before analysing the IBSA intra trade relations it is important to understand current and predicted internal developments of the three economies. Arguably, much of the potential for increasing trade among the three countries will to a certain degree emerge naturally if the economies are growing and diversifying. By taking a look at the current size of the economies of IBSA countries it is obvious that the three anchor countries are the economic powerhouses within their respective regions. ${ }^{2}$ India's gross domestic product (GDP) amounted to US\$ 906 billion in 2006 (almost $80 \%$ of the GDP of the South Asia region). It must be noted, however, that China (with its GDP of US\$ 2,668 billion in 2006 in the neighbouring region of East Asia and Pacific) needs to be taken into account for the economic power relations of the Asian continent. Brazil's GDP at US $\$ 1,068$ billion in 2006 represented $36 \%$ of the GDP in the region of Latin American and the Caribbean. Brazil is followed by Mexico but clearly ahead of the other states in South America. South Africa's GDP reached US\$ 255 billion in 2006 which was about $36 \%$ of the GDP of sub-Saharan-Africa, subsequently leaving Nigeria as runner-up with a GDP of US\$ 115 billion in 2006 far behind.

These GDP figures clearly show the economic supremacy of the IBSA countries in their respective regions. If one also takes India and Brazil's recent growth rates in account and their projections for economic development in 
decades to come, these countries are not only considered regional powers, but also global growth poles.

For his growth predictions for 34 countries, BERGHEIM (2005) uses a complex model that for instance even tries to capture the development of human capital. For the IBSA countries he projects India's economy to grow on average by $5.5 \%$ until 2020 making it the top growth pole in the developing world. The projection for Brazil is a more moderate $2.8 \%$, while the paper abstains from a projection for South Africa due to the expected increase and not foreseeable consequences of HIV/AIDS for the economy. An analysis by WILSON/PURUSHOTHAMAN (2003) yields projections until 2050. According to them India will become the third largest economy by 2050 behind China which is supposed to be the largest economy by 2050 (followed by the US). Due to this expected development a further increase in Asian regional trade is likely and India and China will remain the key growth poles in Asia and might even become the key growth poles of the world economy. Brazil's GDP is projected to grow continuously and clearly exceed the GDP of major European economies (France, Germany, Italy and the United Kingdom) in 2050. For South Africa they project a development of GDP until 2050 which will not exceed the GDP of the above mentioned European economies. But certainly South Africa will by far remain the largest and most advanced economy in Sub-Saharan Africa, in fact it is highly likely that it will even extend its lead.

Furthermore, two other aspects deserve attention to fully understand the future potential of the IBSA countries: the projected significant increase in population and GDP per capita. According to the United Nations (UN 2006) in 2000 about 1.2 billion people lived in the IBSA countries, for 2050 this figures is projected to increase by nearly $60 \%$ to 1.9 billion. In comparison, Europe hosted about 730 million people in 2000, probably declining to 650 million in 2050. India alone has figures that far outstretch Europe. From around 1 billion in 2000 India's population is predicted to grow to 1.6 billion in 2050. WILSON/PURUSHOTHAMAN (2003) predict that India's economic growth will be nevertheless strong enough to push the GDP per capita from less than US\$ 500 in 2000 to more than US\$17,000 in 2050. In comparison to India's gigantic figures, Brazil and South Africa represent small populations. Brazil currently has a population of approximately 200 million, while 45 million people reside in South Africa. However, these countries constitute as well as India important markets. This has to be even further emphasised as the purchasing power of both anchor countries will rise significantly. Brazil's GDP per capita is supposed to rise from around US $\$ 4,000$ in 2000 to almost US\$27,000 until 2050 and the per capita GDP of South Africa is even supposed to increase to nearly US $\$ 40.000$ by 2050 (WILSON/Purushothaman 2003). However, it remains a crucial question if increased economic growth will lead to less inequality considering the current huge income disparities in IBSA countries ${ }^{3}$. A reduction of inequality is in the case of the IBSA countries not only socially desirable but also economically promising as it would enable more people to buy and consume goods and services thus making the markets more attractive for the domestic private sector and foreign investors.

As a first conclusion one can assume that the significant growth potential of the IBSA economies will most likely result in a further step-by-step opening of their markets, a further diversification of their exports and a significant enlargement of their markets for all kinds of imports as well. If the IBSA countries mutually facilitate seizing these market opportunities, trilateral trade might have significant development potential in the near to long-term.

\section{Current intra IBSA trade developments}

IBSA's New Delhi Plan of Action, which was an outcome of the meeting of the foreign ministers of IBSA in March 2004, sets the target to reach an intra IBSA trade volume of US\$ 10 billion until 2007. While data for 2007 are not yet available, the target seems within reach as in recent years trade among IBSA countries has seen a significant boost. For a detailed analysis of trade flows one has to acknowledge that trade figures often differ to some extent according to the source, the differing national classification standards, statistical coverage of transhipment, the addition of cost of freight etc. ${ }^{4}$ Therefore this paper will not pick a single figure or calculate an average where there is a huge gap in the data but indicate the corridor by looking at reported data by every IBSA 
country and then giving the lowest and highest figure. We will compile trade data for commodities - thus excluding trade in services which is especially in the case of India also becoming more important for South-South trade - using the World Bank's World Integrated Trade Solution (WITS) tool which extracts the data from the United Nations Commodity Trade Statistics Database (COMTRADE). This shows the following trade developments (see also Tab. 1):

India - Brazil: Commodity trade between India and Brazil amounted to US\$ 346-458 million in 1995 and increased slightly until 2000 to US\$ 377-489 million. Since then the trade volume quintupled to about US $\$ 2.4$ billion in 2006. The balance of trade between India and Brazil saw slight fluctuations since 1995 . Recently though India records a trade surplus of between US\$467-535 million in 2006.
India - South Africa: The development of the commodity trade between India and South Africa shows a rather similar pattern. The trade volume of US\$ 385-581 million in 1995 increased to US\$ 615-747 million in 2000. In 2006 it reached US\$2.4-3.2 billion more than tripling, respectively quadrupling the figures within five years. For 2006 there is a huge gap in reported trade data by the two countries. However, one trend seems clear, the significant increase of trade between India and South Africa has resulted in a trade surplus somewhere between US\$ 847 million and US\$ 1,223 million for India in 2006.

Brazil - South Africa: Commodity trade between Brazil and South Africa stayed constant between 1995 and 2000 at US\$ 496-530 million. Since then it almost quadrupled to US\$ 1.8-1.9 billion in 2006. Along with that the South African trade deficit with Brazil has in-

Tab 1: Intra IBSA trade relations 1995, 2000, 2006 (all trade values in million US\$)

\begin{tabular}{|c|c|c|c|c|c|c|c|c|c|c|}
\hline \multirow{2}{*}{ Reporter } & \multirow{2}{*}{$\begin{array}{c}\text { Trade with } \\
\text { Year }\end{array}$} & \multicolumn{3}{|c|}{ Brazil } & \multicolumn{3}{|c|}{ India } & \multicolumn{3}{|c|}{ South Africa } \\
\hline & & 1995 & 2000 & 2006 & 1995 & 2000 & 2006 & 1995 & 2000 & 2006 \\
\hline \multirow{6}{*}{$\begin{array}{l}\overline{\text { त्ञ̆ }} \\
\text { ติ }\end{array}$} & Export & & & & 320 & 217 & 939 & $n a$ & 302 & 1,463 \\
\hline & Import & & & & 138 & 271 & 1,474 & $n a$ & 228 & 435 \\
\hline & Balance of trade & & & & 182 & -54 & -535 & na & 74 & 1,028 \\
\hline & Total Trade & & & & 458 & 489 & 2,413 & na & 530 & 1,898 \\
\hline & & & & & & $7 \%$ & $394 \%$ & & na & $258 \%$ \\
\hline & $\begin{array}{l}\% \text { Share of countries } \\
\text { global total trade }\end{array}$ & & & & $0.5 \%$ & $0.4 \%$ & $1.1 \%$ & & $0.5 \%$ & $0.8 \%$ \\
\hline \multirow{6}{*}{$\stackrel{\frac{\pi}{\sigma}}{\Xi}$} & Export & 86 & 230 & 1,451 & & & & 338 & 315 & 2,242 \\
\hline & Import & 260 & 148 & 984 & & & & 243 & 431 & 1,020 \\
\hline & Balance of trade & -175 & 82 & 467 & & & & 95 & -116 & 1,223 \\
\hline & Total Trade & 346 & 377 & 2,435 & & & & 581 & 747 & 3,262 \\
\hline & $\begin{array}{l}\text { \% Change to } 1995 \text { resp. } \\
2000\end{array}$ & & $9 \%$ & $546 \%$ & & & & & $29 \%$ & $337 \%$ \\
\hline & $\begin{array}{l}\% \text { Share of countries } \\
\text { global total trade }\end{array}$ & $0.5 \%$ & $0.4 \%$ & $0.8 \%$ & & & & $0.9 \%$ & $0.8 \%$ & $1.1 \%$ \\
\hline \multirow{6}{*}{ 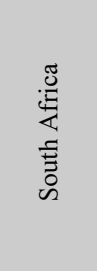 } & Export & 289 & 202 & 407 & 190 & 362 & 783 & & & \\
\hline & Import & 240 & 294 & 1,396 & 195 & 253 & 1,630 & & & \\
\hline & Balance of trade & 49 & -93 & -989 & -6 & 108 & -847 & & & \\
\hline & Total Trade & 530 & 496 & 1,803 & 385 & 615 & 2,414 & & & \\
\hline & $\begin{array}{l}\text { \% Change to } 1995 \text { resp. } \\
2000\end{array}$ & & $-6 \%$ & $263 \%$ & & $60 \%$ & $292 \%$ & & & \\
\hline & $\begin{array}{l}\% \text { Share of countries } \\
\text { global total trade }\end{array}$ & $1.0 \%$ & $0.9 \%$ & $1.5 \%$ & $0 . \quad \%$ & $1.1 \%$ & $2.0 \%$ & & & \\
\hline
\end{tabular}


creased significantly and amounted in 2006 to around US\$ 1 billion.

These figures reveal three main characteristics of the IBSA trade relations since the mid1990s:

First, trade flows between all the three anchor countries have significantly and continuously increased, particularly in recent years.

Second, the relatively well balanced trade relations are changing and resulting in significant trade deficits for South Africa with both Brazil and India. The balance of trade between Brazil and India is not showing such a clear trend.

And third, the target of the New Delhi Plan of Action to reach an intra IBSA trade volume of US\$ 10 billion until 2007 seems within reach. According to the WITS query intra IBSA com- modity trade amounted to US\$ 6.7-7.5 billion in 2006. This is an impressive increase in trade since 2000 for which the WITS query yields trade values of US\$ 1.5-1.8 billion, representing an increase of trade in-between 270-400\% depending on the differing data.

\section{The broader picture: IBSA trade relations outside their alliance}

One has to put the above findings into perspective (see Tab. 2). The trade volumes of all IBSA countries are significantly larger with big trading partners like the US, EU and China than with the IBSA member states themselves. Furthermore, the growth rates of trade with these bigger trading partners also has seen a tremendous increase for all IBSA countries within the same period. This shows that their trade performance - and in the cases of Brazil

Tab. 2: IBSA countries' trade 2000, 2006 (all trade values in million US\$)

\begin{tabular}{|c|c|c|c|c|c|c|c|c|c|}
\hline \multirow{2}{*}{ Reporter } & Commodity Trade with & \multicolumn{2}{|c|}{ World } & \multicolumn{2}{|c|}{ EU25 } & \multicolumn{2}{|c|}{ USA } & \multicolumn{2}{|c|}{ China } \\
\hline & Year & 2000 & 2006 & 2000 & 2006 & 2000 & 2006 & 2000 & 2006 \\
\hline \multirow{7}{*}{ 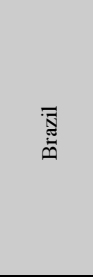 } & $\begin{array}{l}\text { Export } \\
\% \text { Change since } 2000\end{array}$ & 54,744 & $\begin{array}{c}137,147 \\
151 \%\end{array}$ & 15,251 & $\begin{array}{c}30,492 \\
100 \%\end{array}$ & 13,051 & $\begin{array}{c}24,149 \\
85 \%\end{array}$ & 1,085 & $\begin{array}{l}8,402 \\
674 \%\end{array}$ \\
\hline & Import & 55,850 & 91,343 & 14,535 & 20,136 & 13,037 & 14,856 & 1,222 & 7,989 \\
\hline & $\%$ Change since 2000 & & $64 \%$ & & $39 \%$ & & $14 \%$ & & $554 \%$ \\
\hline & Balance of trade & $-1,107$ & 45,805 & 717 & 10,356 & 14 & 9,292 & -137 & 413 \\
\hline & Total trade & 110,594 & 228,490 & 29,786 & 50,628 & 26,088 & 39,005 & 2,307 & 16,392 \\
\hline & $\%$ Change since 2000 & & $107 \%$ & & $70 \%$ & & $50 \%$ & & $610 \%$ \\
\hline & $\%$ Share of Total Trade & & & $27 \%$ & $22 \%$ & $24 \%$ & $17 \%$ & $2 \%$ & $7 \%$ \\
\hline \multirow{7}{*}{ 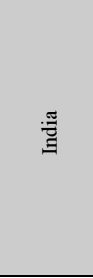 } & $\begin{array}{l}\text { Export } \\
\% \text { Change since } 2000\end{array}$ & 45,250 & $\begin{array}{c}126,124 \\
179 \%\end{array}$ & 10,849 & $\begin{array}{c}26,575 \\
145 \%\end{array}$ & 9,455 & $\begin{array}{c}18,862 \\
99 \%\end{array}$ & 844 & $\begin{array}{l}8,279 \\
881 \%\end{array}$ \\
\hline & Import & 47,136 & 170,950 & 10,002 & 28,867 & 3,062 & 11,671 & 1,528 & 17,428 \\
\hline & $\%$ Change since 2000 & & $263 \%$ & & $189 \%$ & & $281 \%$ & & $1041 \%$ \\
\hline & Balance of trade & $-1,886$ & $-44,826$ & 847 & $-2,292$ & 6,393 & 7,190 & -683 & $-9,149$ \\
\hline & Total trade & 92,386 & 297,074 & 20,851 & 55,441 & 12,518 & 30,533 & 2,372 & 25,707 \\
\hline & $\%$ Change since 2000 & & $222 \%$ & & $166 \%$ & & $144 \%$ & & $984 \%$ \\
\hline & $\%$ Share of Total Trade & & & $23 \%$ & $19 \%$ & $14 \%$ & $10 \%$ & $3 \%$ & $9 \%$ \\
\hline \multirow{7}{*}{ 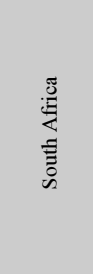 } & $\begin{array}{l}\text { Export } \\
\% \text { Change since } 2000\end{array}$ & 30,187 & $\begin{array}{c}53,001 \\
76 \%\end{array}$ & 8,669 & $\begin{array}{c}18,814 \\
117 \%\end{array}$ & 2,409 & $\begin{array}{l}6,140 \\
155 \%\end{array}$ & 335 & $\begin{array}{l}2,137 \\
538 \%\end{array}$ \\
\hline & Import & 26,785 & 69,172 & 10,729 & 23,989 & 3,187 & 5,271 & 996 & 6,951 \\
\hline & \% Change since 2000 & & $158 \%$ & & $124 \%$ & & $65 \%$ & & $598 \%$ \\
\hline & Balance of trade & 3,402 & $-16,171$ & $-2,060$ & $-5,175$ & -778 & 869 & -661 & $-4,814$ \\
\hline & Total trade & 56,971 & 122,174 & 19,398 & 42,802 & 5,596 & 11,411 & 1,331 & 9,089 \\
\hline & $\%$ Change since 2000 & & $114 \%$ & & $121 \%$ & & $104 \%$ & & $583 \%$ \\
\hline & $\%$ Share of Total Trade & & & $34 \%$ & $35 \%$ & $10 \%$ & $9 \%$ & $2 \%$ & $7 \%$ \\
\hline
\end{tabular}


and India especially the export performance has been generally positive. CHAKRABORTY/ SENGUPTA (2006) point to the important observation that China is in fact the most dynamic trading partner of IBSA counties in the developing world. Consequently they are considering the possible consequences for trade development and political power in areas of global governance if IBSA would be joined by China.

The information below is extracted from the WITS query and illustrates the following details regarding the IBSA member countries and their trade patterns outside IBSA:

India's total trade flow (exports plus imports) amounted to US\$ 297 billion in 2006. India's main trading partner in 2006 (with a $19 \%$ share of India's total trade) was the EU and its 25 member states (EU 25). The EU 25 was then followed by the US (10\%) and China (9 $\%)$. Trade with the IBSA partners represented only $2 \%$ of India's trade in 2006. India's trade with the neighbouring countries of the South Asian Association for Regional Cooperation (SAARC) is comparatively insignificant.

Brazil's trade exchange with the world was US\$ 228 billion in 2006. The EU 25 represented Brazil's most significant trading partner with a share of $22 \%$ of total trade. The US followed the EU closely with $17 \%$ share of Brazil's trade in 2006. Brazil's trade with China has increased enormously since 2000 and in 2006 it represented $7 \%$ of Brazil's global trade. After stagnation from 2001-2003, Brazil's trade with its Mercosur partners has gained momentum and constituted $10 \%$ of Brazil's total trade in 2006.

South Africa traded $35 \%$ of its trade of US\$ 122 billion in 2006 with the EU 25. During the same period, the US accounted for $9 \%$ of total trade, while China made up $7 \%$. It is noticeable (and applies for India and Brazil as well) that the share of trade with China has consistently increased whereas, even though not in total numbers, the share of trade with the US has decreased. The share of the EU 25 in South African trade is stable, unlike in Brazil's and India's trade where the share of the EU 25 is decreasing. South Africa's trade with the partner countries of the Southern African Customs Union (SACU) ${ }^{5}$, as well as with SADC countries, is very significant. For South Africa, trade with the whole of Sub-Saharan Africa represented $10 \%$ of its entire trade in 2006. South Africa clearly benefits from trade with Sub-Saharan Africa as its exports to the region amounted to $14 \%$ of its total exports, whereas imports from the region constituted only $6 \%$ of all South African imports.

From the information presented above about IBSA trade relations, it is fair to conclude that intra IBSA trade is not the priority area for trade for the three anchor countries. However, if one adds China to the equation, it is clear that developing country cooperation is becoming increasingly significant for all IBSA members. And the above average growth trend of trade development among IBSA countries - plus China - suggests that there is potential to continue on this path, at least in the short-run. However, is this likely? And what are the long-term objectives of the member states in the IBSA alliance?

Some studies and research projects on IBSA have tried to disentangle the complex trade relations to identify promising areas for future cooperation, as well as bottlenecks and challenges that limit a further increase of trade volumes. The findings of these studies regarding the current composition of trade are diverse, and to a certain extent reach different conclusions. A detailed study by the Indian Research and Information System for Developing Countries (RIS 2005) shows that intra IBSA trade is taking place in few, though still a significant number of sectors: mineral products (fuels, oils), products of chemicals (pharmaceuticals and organic chemicals), plastics and articles thereof, vegetable products (esp. cereals), machinery and mechanical appliances and base metals and articles of base metals. One should take into consideration that the export of gold from South Africa is constituting a significant share of the exports to India which is apparently not reported in South African trade statistics (see SANDREY/JENSEN 2007, 14f.).

The RIS study also shows that India's exports to Brazil, and as well to South Africa, are more diversified than the ones between Brazil and South Africa, as well as of both anchor countries to India. Nevertheless, for all intra IBSA trade it is stated that there is a lack of persistence in a number of exports. This is reflected in erratic trade relations that are probably the result of ad-hoc business opportunities. Thus, established trading networks in IBSA-value chains seem to be rather uncommon till now. 
It remains an open question as to which sectors the most potential lies for increasing intra IBSA trade volumes. SoKo (2006) suggests that this may be in the already strong sectors. There is potential for South Africa, for instance, to import more affordable medicines from India. India, on the other hand, is an increasingly important market for South African gold, silver, coal, iron and steel. Soko also regards South African mining exports to Brazil as very relevant, and highlights the investment by South African mining companies in Brazil (and in South America generally).

On the other hand, relatively weak performing sectors in current intra IBSA trade might become future backbones. For Indian exports to Brazil and South Africa this is suggested by RIS (2005) to be the textile sector. For India's exports to South Africa it is even suggested that textile and textile articles will become the strongest export sector. Further, it is projected that the export of the already strong sector of products of chemicals from India to Brazil will see the highest growth rates.

\section{Existing bottlenecks to intra IBSA trade expansion}

According to a variety of studies, the expansion of intra IBSA trade is faced with various bottlenecks. Hindrances to cooperation, for example, include:

Insufficient transport connectivity as a result of low demand for direct connections: DE (2005) sees the current weak transport connectivity as one of the strongest barriers to increased intra IBSA trade. Most of intra IBSA trade is carried out by sea freight. The three anchor countries already host a significant number of ports including the deep water ports Tubarão (Brazil) and Richards Bay (South Africa). New deep water port development projects are under way like the Vizhinjam port project of Kerala State in southern India and the Port of Ngqura which is embedded in the ambitious South African Coega Industrial Development Zone project. However, despite theses current and future capacities to handle all sorts and high quantities of goods and freight, there are currently no regular services connecting the three anchor countries. As a result of the lack in connectivity transhipment via Asian, European or North American trade hubs is costly and time consuming (see FONSECA/ Azevedo/Velloso 2005). The airlinks between IBSA countries also seem to be underdeveloped. Only South African Airways serves destinations in Brazil and India. Business relations are often difficult due to the sheer distance that one is required to travel to either Brazil or India. Businessmen find it timely to travel to these destinations, with uncomfortable stopovers in Europe or the US (see DE 2005; KULKARNI 2005).

Lack of awareness of IBSA and market information among the private sector in all three anchor countries: This becomes apparent in a series of field survey reports (ICONE 2005; KULKARNI 2005; SOKO 2006). It is reported for Brazil that only $25 \%$ of the interviewed businesses were aware of IBSA. North American and European markets are the most relevant for Brazilian companies and that development of these markets or further in-depth exploration is the priority for the majority of businesses (see ICONE 2005). The responses in the two other field surveys showed similar low levels of awareness of IBSA. In some cases it is even reported that business people expressed explicit criticism and scepticism towards IBSA mainly arguing that initiatives of this kind are more political but not benefiting the private sector. A very interesting comment for Brazil states that "The existing dichotomy between geopolitical versus trade objectives is becoming a serious national issue in Brazil. The private sector objects intensely to commercial agreements that do not generate commerce or, worse yet, that may produce an unbalanced quid-pro-quo between increased competition in the national market and increased access to international markets". (ICONE 2005, 31). Pointing to the importance of interests at the domestic level MiLdnER/Husar (2007) analyse the interests and governance of trade policy in IBSA countries. ${ }^{6}$ They find that it is rather the protectionist groups at the domestic level which are successful in safeguarding their interests.

Non-harmonised standards and regulations slow down trade and make it more costly due to information and compliance costs. Currently India, Brazil and South Africa are using different regulations for import controls. Also standards regarding health and safety measures are not harmonized in IBSA. RIS (2005) therefore sees a clear priority for cooperation of 
governments and public authorities to create a common IBSA framework that will enable easier trade for businesses, increase transparency and improve uniformity of standards and regulations.

\section{Possible ways forward to stimulate intra-IBSA trade}

There are various models being considered to possibly increase the trade flows between IBSA member states. Models range from an IBSA preferential trade agreement (PTA) to an India-Mercosur-SACU Trilateral Free Trade Area (T-FTA) - which is stylized in the "Joint Declaration of the First IBSA Summit Meeting in Brasilia" in September 2006 (see South Centre 2006). ${ }^{7}$ Clearly a mutual liberalisation to enable market access will be a controversial issue in all three anchor countries which is already reflected in the sceptical views of parts of the private sector reported above. On the other hand FugAZZA/VANZETTI $(2006,7)$ are arguing that "by seeking exemptions for sensitive products in their markets, developing countries are inadvertently limiting the trade opportunities of other developing countries." And indeed bitter bargaining encouraged by protectionist business interests in all three anchor countries would reduce the vision of Brazilian President Luiz Inácio Lula da Silva's "new world economic and commercial geography" to absurdity.

The three governments have embarked on an ambitious new project of South-South cooperation which requires their constant commitment and support to deepen political and economic ties. Reducing tariff and non-tariff trade barriers (e.g. by harmonising regulations and standards) is an immediate task for the public sectors in all three IBSA countries. Selective government intervention seems to be appropriate in areas of information campaigns, the facilitation of initial business contacts and the improvement of the transport connectivity. However, it remains clear that in the end it will depend on the existence of intra IBSA profit-making business opportunities. Identifying these opportunities will involve search costs that can only partly be absorbed by the public sector. This leads us to conclude that the future strengthening of the economic pillar of IBSA is now primarily up to the private sector.

\section{Science and technology - an important rationale for South-South cooperation}

Technological learning and acquisition of innovation capabilities is a key to economic development and structural change. This is one of the basic lessons that can be drawn from the (limited number of) real success stories in development (South Korea, Taiwan, Costa Rica). Technological upgrading of the given industrial structures leads to rising productivity, and thus, increasing factor remuneration. Furthermore, science and technology are important enablers related to most non-income dimensions of development (health, education). Also, it is becoming increasingly clear, that without the provision of important ecological innovations (e.g. low carbon technologies), the imminent threats to the global environment (climate change) can not be averted.

For a long time, emphasis has been placed on North-South transfer of advanced equipment and know-how as a means of narrowing the gap between developed and developing countries. It was assumed that the scientific and technological capacities in the South are too limited to induce sufficiently steep technological learning curves. UN-organizations like UNESCO, UNCTAD and the UN Commission of Science and Technology for Development (CSTD) have been pushing forward these topics for decades. For the most part, these agendas were driven by developing countries' representations, mainly the G77. Several international events and documents (Vienna Conference on Science and Technology for Development 1979, Bangkok Plan of Action 2000, Havana Programme of Action 2000) reflect the desire of developing countries to receive access to new technological know-how and artefacts (UNCTAD 2000; G77 2000).

Several international agreements incorporate the issue of North-South technology transfer as a means to achieve development and environmental objectives, e.g. the UN Convention on Biological Diversity, the UN Framework Convention on Climate Change, and the UN Convention to Combat Desertification. One of the most far reaching of these agreements is the WTO agreement on Trade Related Intellectual Property Rights (TRIPS). According to Article 7: "The protection and enforcement of intellectual property rights should contribute to the promotion of technological innovation and to 
the transfer and dissemination of technology, ..." (WTO 1994). While this article defines international technology transfer as an important but still vague international goal, the agreement gets much more concrete in its Article 66.2, which states: "Developed country members shall provide incentives to enterprises and institutions in their territories for the purpose of promoting and encouraging technology transfer to least-developed country members in order to enable them to create a sound and viable technological base." MASKUS $(2003,2)$ highlights the fact, that the mentioned WTO agreement defines only obligations of developed countries regarding least developed countries, and that no obligations or rights are created for the developing and transition countries.

All these diplomatic efforts, international agreements and commitments of the North have achieved relatively little, with regard to concrete technological catching-up in the South. Besides the question of real willingness of Northern countries' actors to actively engage in technology transfer, a series of factors help to explain this limited success:

- Technological learning is cumulative, implying that it happens much quicker, where already a reasonable knowledge base exists.

- Technological knowledge has important tacit components, elements that are difficult to codify and thus, "sticky" and difficult to transfer to other locations.

- Technology is developed based on the factor endowment of the respective market. Thus, Northern technology is often, contrary to the Southern countries needs, capital intensive and labour extensive.

- Technological knowledge generated in the North, especially in areas like agriculture or health is not ready to be applied in the South, but has "to be translated to the ecological specificities of a different part of the world" (SACHS 2002, 8).

The North-South technology transfer model has, thus, led to rather disappointing outcomes. Recently, the outlook regarding North-South technology transfer is becoming even more vague, as research and development activities in the North are gradually shifting from public to private actors, less willing to share new knowledge with actors in the South. Thus, since around 2000, Southern countries are moving towards South-South cooperation as a means to accelerate technological learning. The already mentioned Havana Programme of Action calls for intensified efforts of developing countries to develop endogenous scientific and technological capacities and for increased South-South cooperation in areas such as bioengineering, communication, administration and production, education, transport and software development. (G77 2000). In the same year (2000), the Seoul Accord on South-South Cooperation in Science and Technology recommended the establishment of networks and mechanisms among Southern countries, an initiative "directed at galvanizing South-South initiatives for solving problems that attract little interest in the developed North" (JumA et al. $(2005,61)$.

The clearest reflection of a renewed impetus in South-South cooperation in knowledge generation is the Africa's Science and Technology Consolidated Plan of Action, approved in 2005 by the New Partnership for Africa's Development (NEPAD) initiative. The action plan formulates two very ambitious goals, namely: a) to enable Africa to harness and apply science, technology and related innovations to eradicate poverty and achieve sustainable development; and b) to ensure that Africa contributes to the global pool of scientific knowledge and technological innovations (NEPAD 2005, 10).

\section{Science and Technology in the context of IBSA cooperation}

The Brasilia Declaration already stresses the potential synergies that can be derived from cooperation in science and technology development, stating that the three anchor countries have diverse areas of high-level expertise. Possible areas of cooperation mentioned in the document are biotechnology, alternative energy sources, outer space, aeronautics, information technology, agriculture and defence. A trilateral working group to explore promising areas and mechanisms of cooperation was set up. Annual meetings on ministerial level are guiding the activities.

First steps : During the third meeting of the departmental ministers in 2006, it was decided 
that, in order to initiate collaboration among scientific and technological communities of the three anchor countries, a joint IBSA science and technology funding allocation will be established. The countries committed themselves to mobilize US\$ 1 million each for collaborative activities (Internet: http://www. mrc.ac.za/funding/ibsaguidelines.pdf, 7.1.2008. Cooperation shall in a first phase be focussed on a limited number of research fields, one of the three anchor countries is given a lead position for each of them. The first most important area is medical and pharmaceutical research, to combat the most important diseases afflicting the three anchor countries, but also many of the countries in their respective world region: HIV/AIDS (Lead: India), malaria (Brazil), tuberculosis (South Africa). Furthermore, research in nanotechnology (India), biotechnology (South Africa), oceanography (Brazil) and recently Antarctic research are among the prioritized disciplines.

First assessment: Till date, empirical evidence regarding the possible outreach of South-South science and technology cooperation within the frame of IBSA is extremely scarce. The signals emanating from the political level are mixed, regarding the priority given to this project and the objectives that shall be achieved:

Focusing on tropical diseases is a very feasible undertaking, reflecting the fact that Northern countries tend to under-invest in combating these illnesses as they do not afflict their populations. India has the largest and most advanced pharmaceutical industry in the whole developing world, ranking fourth worldwide regarding production and 13 regarding sales volumes. The industry's special strength is the production of active pharmaceutical ingredients (APIs) and of generics (LÖFGREN/MALHOTRA 2006).

Bio- and nanotechnologies are considered strong candidates as technologies that may trigger a new Kondratieff-type long wave of economic growth (see WONGLIMIYARAT 2005). Thus, as all three IBSA member countries perceive themselves as emerging global players, it makes sense for them to try to get foothold in these fields. Brazil has a developed science and technology base in biotechnology, including genetic engineering of e.g. soy beans and sugar cane for ethanol production. And as some mayor challenges related to biological sciences are similar in the three anchor countries (assuring food provision to the population, emerging competition between food and energy production), South-South cooperation is an interesting option in this field. Regarding Nanotechnologies, this seems less clear.

There are good reasons to consider Intra-IBSA cooperation in a series of science and technology related fields promising. However, the concrete action taken by the three governments is not very ambitious, for the time being. The seed-capital mobilized to induce cooperation among researchers of the three countries (US\$ 1 Million per country) is very limited, e.g. compared to the global research and development (R\&D) spending of US\$ 7.5 billion in 2005 in the case of Brazil. It also has to be considered, that a series of disincentives exist for researchers and technology developers to engage in cooperation within IBSA: a) Intra-IBSA cooperation runs counter established directions of science and technology cooperation, e.g. between India and the United Kingdom. Language still acts as a certain barrier in the case of cooperation of India and South Africa with Brazil. b) For researchers in the South aiming at promoting their academic career it still is of first priority to link-up with the established centres of academic excellence in the North, in order e.g. to gain access to A-rated refereed journals.

\section{Conclusions}

Will IBSA make a difference in the development of North-South and South-South relations? Five years after the inception of the trilateral dialogue it remains rather speculative to predict the possible depth and outreach of the project. Two arguments can be mentioned as promising, taking into consideration the mixed experiences of earlier projects of South-Southcooperation: a) The three anchor countries are among the largest in the developing world, giving the grouping a high political leverage. At the same time, the markets are mutually interesting for the business communities of the three anchor countries. b) In numbers, the grouping is small and the anchor countries share common political beliefs and positions, implying that the centrifugal forces that in the past afflicted other South-South-alliances, such as G77, can be contained. 
The initiative was born with a clear political impetus, aiming to push forward reforms in the global governance architecture. Observers agree that the future of IBSA is critically related to the question, whether the anchor countries will manage to induce cooperation in practical areas, implying a broadening and strengthening of actor networks and the development of mutual confidence. Those pushing forward the alliance pin their hopes on boosting commercial and investment relations and an increased cooperation among the science and technology communities of the three anchor countries. While the process is still too young to provide empirical evidence regarding the development of scientific and technological relations, available data for trade illustrate that in fact the commercial linkages are developing rapidly. However, data also shows that the formation and development of IBSA was and is overlaid by parallel processes, especially the rise of China as a commercial superpower and as a heavy investor both in Africa and in Latin America. To some extent, the future relation of IBSA and its three member countries to China is decisive for the role the alliance can play in future global governance processes. Systematically approaching or even integrating China could significantly raise the leverage of the grouping by sheer size. On the other hand, the attractiveness and role model as an alliance of "three Southern democracies" would have to be sacrificed and a lot more points of conflict would arise within the grouping.

In general, the assessment of IBSA's present and future role is complicated by the fact, that the international political, economic and scientific relations are being reshuffled and that new constellations (such as the "O5"-countries) emerge that to some extent compete with the "G3 of the South". As political, economic and also scientific actors in the North are increasingly acknowledging the growing importance of Brazil, India, South Africa and other anchor countries a growing number of dialogue and cooperation initiatives are being launched on both bilateral and multilateral (Gleneagles Dialogue, Heiligendamm-Process) levels. It remains an open question, to what extent and in which ways these overlapping processes interact with the further deepening of the IBSA alliance. At least two very different scenarios can be sketched: a) IBSA may severely be weakened, because for many actors in diplomacy, business and science, it may increasingly be tempting to react positively to new opportunities that open up when their countries are being approached by OECD countries or China. b) If policy makers are able to manage the complex setting in an intelligent way, strengthening of IBSA can reinforce the global role the anchor countries are increasingly playing and invited to play by Northern countries, as an effective alliance can further strengthen the bargaining power of Brazil, India and South Africa in international dialogues and negotiations. Thus, for the years to come, the IBSA process opens a lot of research opportunities, not least for economic and political geographers.

\section{Notes}

1 Quote from the speech of Brazilian President Luiz Inácio Lula da Silva at the opening of the General Debate of the 59th session of the General Assembly of the United Nations, New York, 21st September 2004.

2 World regions according to World Bank definition, which means that all mentioned regions include developing countries only. All GDP data taken from World Development Indicators online. Internet: www.worldbank.org/data, 3.1.2008

3 Gini-index according to UNDP (2007) for: Brazil 57.0 (survey year 2004); South Africa 57.8 (2000); India with a lower Gini-index of 36.8 (2004-05) but with $34.3 \%$ of the population living on less than US\$ 1 a day (see UNESCAP 2007, 35).

4 For instance according to SANDREY/JENSEN (2007) there are some methodological issues to consider when dealing with South Africa's official trade data for the year 2005. In different sources of trade data a remarkable difference in the figures of Indian imports from South Africa respectively South African exports to India becomes apparent. They provide as a possible explanation for these inconsistent figures that South Africa is not reporting its exports of gold. According to them gold is by far the largest share of South African exports to India and amounted to US\$ 1.85 billion in 2005. In addition to that the Indian import figures are not taking into account South African aircraft exports to India in 2005 worth US\$ 250 million. If one subtracts the figures for gold and adds the figures for aircraft the import/export figures reported by both countries as given in their paper are indeed more consistent.

5 Other members are Botswana, Namibia, Lesotho, Swaziland.

6 Their research is inspired by PuTnAM's (1988) considerations on two level games of governments at the international and domestic level.

7 It should be briefly mentioned that issues of WTO conformity and the involvement of regional trade blocs (Mercosur, SACU) in the negotiations is seen as problematic in the literature. 


\section{Literature}

AldEn, C./VieIRA, M.A. (2005): The new diplomacy of the South: South Africa, Brazil, India and trilateralism. In: Third World Quarterly, (26)7, 1077-1095.

ANTKIEWICZ, A./Whalley, J. (2006): BRICSAM and the non-WTO. In: The Review of International Organizations, (1)3, 237-261.

Avramovic, D. (1988): South-South co-operation. Challenges and Opportunities. In: Singer, H.W./Hatti, N./Tandon, R. (Eds.): Challenges of South-South cooperation. New Delhi, 15-48.

Aykut, D./RATHA, D. (2003): South-South flows: How big are they? In: Transnational Corporations, (13)1, 149-176.

BERGHEIM, S. (2005): Globale Wachstumszentren 2020: Formel-G für 34 Volkswirtschaften. Frankfurt am Main. (Deutsche Bank Research - Aktuelle Themen Nr. 313).

Chakraborty, D./SEngGupta, D. (2006): IBSAC (India, Brazil, South Africa, China). A potential developing country coalition in WTO negotiations. New Delhi. (Centre de Sciences Humaines/CSH, Occasional Paper No 18 / 2006).

DE, P. (2005): Trade in IBSA economic cooperation: The role of transport linkages. New Delhi. ( Research and Information System for Developing Countries/RIS, Discussion Paper \# 104).

Draper, P./Mills, G./White, L. (2004): Much ado about something? Assessing the potential of the IndiaBrazil-SA Forum. Johannesburg. (South African Institute of International Affairs/SAIIA, Report No. 46).

FLEMES, D. (2007): Emerging middle powers' soft balancing strategy: State and perspectives of the IBSA Dialogue Forum. Hamburg. (German Institute of Global and Area Studies/GIGA, Working Papers No. 57).

FonsecA, R./Azevedo, M.S./Velloso, E. (2005): Trade potential between Brazil and India.An examination based on comparative advantage structures. Brasília. (Confederação Nacional da Indústria/CNI Studies 1).

Fugazza, M./VAnzetTi, M. (2006): A South-South survival strategy. The potential for trade among developing countries. New York, Geneva. (UNCTAD Policy Issues in International Trade and Commodities Study Series No. 33).

G77 (Group of 77)(2000): Havana Programme of Action. South Summit 10-14 April 2000, Havana, Cuba. Havanna. (Internet: http://www.nam.gov.za/documentation/southact.htm\#KNOWLEDGE\%20AND\%20TE CHNOLOGY, 7.1. 2008).

Hurrell, A. (2006): Hegemony, liberalism and global order: what space for would-be great powers? In: International Affairs, 82, 1-19.

ICONE (2005): Field survey report: Brazil. South-South economic cooperation: Exploring IBSA (India-BrazilSouth Africa) initiative. São Paulo. (mimeo).

Juma, C. /Gitta, C./ Disenso, A./ Bruce, A. (2005): Forging new technology alliances. The role of SouthSouth cooperation. In: UNDP (Ed.) Cooperation South 2005. New York, 59-71.
KEET, D. (2006): South-South strategic challenges to the global economic system and power regime. Johannesburg. (Institute for Global Dialogue/IGD, occasional paper no 53).

KULKARNI, P. (2005): Field survey report: India. SouthSouth Economic Cooperation: Exploring IBSA (IndiaBrazil-South Africa) initiative. (mimeo).

Kumar, N./Agarwala, R. (2006): Seizing new opportunities for South-South cooperation. Some proposals for the 14th NAM Summit. New Delhi. (Research and Information System for Developing Countries/RIS, Policy Briefs \# 26).

LANGHAMMER, R.J. (1988): Developing countries' manufactured exports and South-South trade in primary commodities: On South-North and South-South trade interdependencies. In: Singer, H.W./Hatti, N./Tandon, R. (Eds.): Challenges of South-South co-operation. New Delhi, 614-641.

LÖFgren, H./Malhotra, P. (2006): Der Aufstieg der indischen Pharmaindustrie. Transformation der globalen Wettbewerbslandschaft? In: Peripherie, (26)103, 315-337.

Maskus, K.E. (2003): Technology transfer and technological capacity building. ICTSD-UNCTAD Dialogue, 2nd Bellagio Series on Development and Intellectual Property, 18-21 September 2003. Internet. http://www.iprsonline.org/unctadictsd/bellagio/docs/M askus_Bellagio2.pdf, 7.1. 2008.

Mildner, S.-A./HusAR, J. (2007): Indien, Brasilien und Südafrika in der Doha-Runde. Handelspolitische Interessen und Entscheidungsstrukturen. Berlin. (Stiftung Wissenschaft und Politik/SWP, Diskussionspapier Oktober 2007).

NEPAD (New Partnership for Africa's Development)(2005): frica's science and technology consolidated plan of Action. August 2005: Internet. http://www.nepadst.org/doclibrary/pdfs/doc27_082005 .pdf, 8.1. 2008.

PURI, L. (2007): IBSA - An emerging trinity in the new geography of international trade. New York, Geneva. (UNCTAD Policy Issues in International Trade and Commodities Study, Series No. 35).

PutNAM, R.D. (1988): Diplomacy and domestic politics. The logic of two-level games. In: International Organization, (42)3, 427-460.

RIS (Research and Information System for Developing Countries)(2005): India-Brazil-South Africa (IBSA) economic cooperation. Towards an action programme. Draft report to be submitted to Department of Commerce, Ministry of Commerce and Industry, Government of India. New Dehli.

SACHS, J. (2002): Science, technology and poverty. Five ways to mobilize development in low-income countries. In: IAES Bulletin, (44)1, 7-10.

SANDREY,R./JENSEN, H. (2007): Examining the India, Brazil and South African (IBSA) triangular trading relationship. Stellenbosch. (Trade Law Centre for Southern Africa/TRALAC, Working Paper No 1/2007).

Singer, H.W./HATti, N./TANDON, R. (1988): Challenges of South-South co-operation. New Delhi. (two vol.). 
SoKo, M. (2006): South-South economic co-operation: The India-Brazil-South Africa case. Johannesburg. (South African Institute of International Affairs/SAIIA, Trade Policy Report No.12).

South Centre (1996): Enhancing South-South trade. Geneva.

South Centre (2006): First IBSA summit joint declaration. In: South Bulletin, 132, 479-486.

TAYLOR, I. (2005): Africa and the emerging new trade geography. The India-Brazil-South Africa Dialogue Forum and its implications for global governance. Manchester. (Centre for International Politics, Working Paper Series No. 7).

UN (2006): World population prospects: The $2006 \mathrm{Re}-$ vision. New York.

UNCTAD (2000): UNCTAD - 10 th session, Bangkok, 12-19 February 2000: Plan of ation. Geneva.

UNCTAD (2005): Trade and development report 2005: New features of global interdependence. New York, Geneva.

UNCTAD (2006): Trade and development report 2006: Global partnership and national polices for development. New York, Geneva.

UNCTAD (2007): Report of the Secretary-General of UNCTAD to UNCTAD XII: Globalization for development. Opportunities and challenges. New York, Geneva.
UNDP (2007): Human development report 2007/2008. Fighting climate change. Human solidarity in a divided world. New York.

UNESCAP (2007): The millennium development goals: Progress in Asia and the Pacific 2007. Bangkok.

White, L. (2004): South Atlantic relations. From bilateral trade relations to multilateral coalition building. In: Cambridge Review of International Affairs, (17)3, 523537.

White, L. (2006): IBSA - A state of the Art. In: South African Year Book of International Affairs (forthcoming). (Paper presented at Universidad de San Andrés conference "Los poderes emergentes y la seguridad regional: el caso IBSA", Buenos Aires $30^{\text {th }}$ of May 2006).

Wilson, D./Purushothaman, R. (2003): Dreaming with BRICs: The path to 2050. New York. (Goldman Sachs Global Economics Paper No. 99).

WONGLIMIYARAT, J. (2005): The nano-revolution of Schumpeter's Kondratieff cycle. In: Technovation. (25)11, 1349-1354.

WTO (World Trade Organization)(1994): Agreement on trade-related aspects of intellectual property rights. Geneva. Internet: http://www.wto.org/english/tratop_e/ trips_e/t_agm2_e.htm, 7.1.2008. 